2009

\title{
From the Bodies of Bees: Classical and Christian Echoes in Surat al Nahl
}

Andrew Foster

Fordham University, foster@fordham.edu

Follow this and additional works at: https://fordham.bepress.com/classics_facultypubs

Part of the Classics Commons

\section{Recommended Citation}

Foster, Andrew, "From the Bodies of Bees: Classical and Christian Echoes in Surat al Nahl" (2009). Faculty Publications. 3. https://fordham.bepress.com/classics_facultypubs/3

This Article is brought to you for free and open access by the Classical Languages and Civilizations at DigitalResearch@Fordham. It has been accepted for inclusion in Faculty Publications by an authorized administrator of DigitalResearch@Fordham. For more information, please contact considine@fordham.edu. 
[CIS 3.2 (2007) 145-168] Comparative Islamic Studies (print) ISSN 1740-7125

doi: 10.1558/cis.v3i2.145 Comparative Islamic Studies (online) ISSN 1743-1638

\section{From the Bodies of Bees: Classical and Christian Echoes in Surat al-Naht*}

\section{J. ANDREW FOSTER AND KATHRYN M. KUENY}

Fordham University

Within Surat al-Nahl, the bee, like the very earth and God's most privileged human hierophants, receives a direct revelation from the Lord. This revelation consists of a series of injunctions: go to your homes, eat of the earth's fruits and "follow the trodden paths of the Lord." These key elements of the Sura's meditation upon the bee resonate very strongly with Classical and Christian ideas about the nature and habit of bees. Just as the Sura privileges the bee to communicate directly with God and to live an ideal life, throughout GraecoRoman Antiquity the bee was similarly thought to be a creature particularly endowed with a divine nature and entrusted with divine revelation. And like their perfectly obedient Muslim counterparts, the Classical bee offered a paradigm for life and how to live it. And yet, Muslim exegetes both Sunni and Shi'i are hardly satisfied to merely import a pre-fabricated trope into their discourse as their rich interpretive tradition elaborates the bee's rhetorical valence and symbolic power to make the insect wholly their own.

Within Surat al-Nahl the Quran sets forth a number of signs drawn from nature. Rain, milk, dates, grapes and honey each embody the same paradox. Like the parched, dead earth, the wine of dates and grapes can debilitate. Cows contain blood and feces. Honey is bees' vomit. Yet also, like the rain sent from God, cows produce refreshing milk, dates and grapes a succulent juice and bees, honey, "a medicine for men [fihi shifa'un li 'l-nasi]." The nourishing from the noxious, the pure from the putrid, even life from death-each of these foods and drinks illustrates the extent to which God's ineffable goodness permeates the cosmos. Degeneration, decay and death are causes necessary to ensure an ongoing cycle of birth, growth and regeneration. Milk, honey, dates and grapes encapsulate this paradox.

As the Sura enumerates these signs, it curiously digresses to speak of the bee in and of itself. Strikingly, the bee, like the very earth and God's most privileged human hierophants, receives a direct revelation [wahy] ${ }^{1}$ from the Lord. This revelation consists of a series of injunctions: go to your homes, eat of the earth's fruits and "follow the ways of your Lord, made smooth" (Sura 16:69).

The life and habits of bees thus so differs from all of the other animals. They alone are entitled to receive precepts directly from the Lord. By implication their manner of living reflects their natural capacity to intuit and apply God's injunctions. Bees are true believers. 
And practitioners. By living as they do, bees assiduously implement God's commands. Simple observation of their behavior readily confirms their perfect obedience to the divine will. The bee and its society exemplify submission to the will of God.

\section{The Classical Bee}

The key elements of the Sura's meditation upon the bee resonate very strongly with Classical and Christian ideas about the nature and habit of bees. Just as the Sura privileges the bee to communicate directly with God and to live an ideal life, throughout Graeco-Roman Antiquity the bee was similarly thought to be a creature particularly endowed with a divine nature and entrusted with divine revelation. And like their perfectly obedient Muslim counterparts, the Classical bee offered a paradigm for life and how to live it.

Unlike the Islamic tradition, neither the Greeks nor Romans ever record a god addressing the bee. It is not surprising. Within the Graeco-Roman tradition gods did not explicitly convey their truths to humans let alone animals. Gods and mortals communicated through more oblique means.

Human prayers, hymns and sacrifices hoped to be heard, but confirmation of their receipt was divined only indirectly, either ex eventu or via a sign, omen, or portent. The proactive will of the gods was also expressed and understood interpretatively. Seers, prophets and diviners such as the Roman Sybil and Pythian priestess at Delphi disclosed the will of the gods. But they only spoke in riddles. Nature herself offered an abundance of divine signs. The flight of birds, a clap of thunder, the movements of the stars in the sky all potentially offered a clue to what a god might portend. Of the animals thought to provide an insight into the mind of a god, the bee, its habits and honey were among the most illuminating.

Swarming bees offered a sign of things to come. For Romans, more often than not the approach of a swarm portended ill. Scipio Africanus refused to do battle with the Carthaginians at Ticinus until the ominous prodigy of swarming bees had been expiated (Livy 21.46.2). The Romans still lost the battle. For the historian Cassius Dio bees swarming inauspiciously were among his generic prodigies of impending ill.?

For Greeks, swarming bees more often were harbingers of success. ${ }^{3}$ According to Himerius, bees led Athenian colonizers to Ionia (Him. Orat. 59.3). ${ }^{4}$ An Ionian colonizer, Timesias, was also guided to the site of his new polis by a host of bees (Plut. Mor. 96b5-6). The criminal architect and reputed son of Apollo, Trophonius, was swallowed up by the earth as he fled the wrath of king Hyrieus whom the builder had cleverly duped of his treasure. ${ }^{5}$ Later, according to Pausanias (9.40.2), all of Boeotia was afflicted by a drought. The oracle at Delphi instructed the Boeotians to learn a cure from the vanished Trophonius. 
Unfortunately, the site of his oracle was unknown-until a swarm of bees led a shepherd to the spot where Trophonius had disappeared, the spot where his oracle was established.

Bees themselves are a source of poetic and prophetic inspiration. At the close of the Homeric Hymn to Hermes, the god of prophecy par excellance, Apollo offers his thieving brother, Hermes, a consolatory gift of "bee maidens" who have a share in the prophetic arts (h.Hom. 4.552-66). These three maidens when fed with honey flit about and offer true prophecy (h.Hom. 4.560-1). If starved, they will lie (h.Hom. 4.562-63).

Bee swarms as a form of divination and prophetic maidens behaving as bees speak to a connection between bees and prophecy. ${ }^{6} \mathrm{~A}$ smattering of anecdotal details strengthens the link. According to Pausanias (10.5.9), the first temple housing the oracle of Apollo was built of laurel branches. Bees constructed the second with their wax. Birds contributed their feathers. A third was made of bronze. The fourth was built by the very Trophonius who was found by a swarm of bees. The myth of bird feathers and beeswax points to a time when these two creatures dominated the prophet's imagination.' It should also be noted that the fifth-century BCE poet Pindar calls the Pythia, Apollo's inspired priestess, "the Delphic bee" ( $\mu \varepsilon \lambda i \sigma_{0 \alpha s} \Delta \varepsilon \lambda \phi i \delta o s ~[P i . ~ P . ~ 4.60-61]$ ).

Bees figure more prominently in poetic creation and rhetorical eloquence. Poetry, like prophecy, was thought by the Greeks to be inspired by the gods. ${ }^{8}$ Bees and honey serve as a metaphor and metonymy for inspiration and literary production.

Within Plato's Ion, a dialog devoted to the nature of poetic inspiration, Socrates describes the inspired poet in terms of a bee buzzing through a garden collecting nectar. Drawing their inspiration "from the honey flowing fountains in the gardens of the Muses" poets bring forth their melodies "just as bees" (Plato Ion 534a7-b3). ${ }^{9}$ Holy, pure and virginal, ${ }^{10}$ bees are particularly welcome in the untrammeled gardens of the gods. Admired poets and eager students were readily described in similar terms. "For the contentious Hellenistic poet, Callimachus, the bee became an irresistible image by which he could assert the superiority of his sources of inspiration and his resulting poetic production. At the close of his Hymn to Apollo, the goddess, Envy, whispers in Apollo's ear that she only admires the epic poet. A pollo (the god of prophecy no less) retorts:

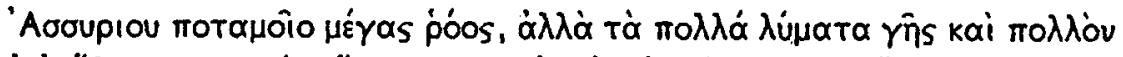

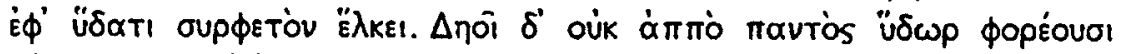

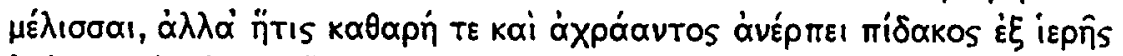

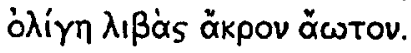

Great is the flow of the Assyrian river, but it drags on its water much filth and garbage. Not from everywhere do bees carry water to Demeter, but only a pure, undefiled tiny trickle drawn from a holy fountain, the best of waters. (Call. Hymn 2.108-12) 
Not long drawn-out epic poems that elaborate worn-out themes, Callimachus writes only delicate, carefully wrought poems drawing his inspiration from only the "purest" sources. He is the literary equivalent of the bee. ${ }^{12}$ No wonder "bees are said to be the birds of the Muses."13

\section{Honey on the Lips of Giants}

Honey has always served as a metaphor for eloquence in Greek literature. In Homer, the aged counsellor, Nestor possessed such rhetorical grace that speech flowed from his tongue "sweeter than honey" (Il. 2.249). This rhetorical commonplace is repeated in Homer and subsequent literature. ${ }^{14}$

The prodigious and inspirational qualities of bees and their honey coalesce in an anecdote repeatedly told of the literary giants of the classical tradition. Pindar, Sophocles and Plato were all said to have shared a similar experience. Plato in his infancy was lying outdoors. He was visited by a swarm of bees. After alighting upon the infant's mouth for a few moments, the bees departed leaving the baby Plato unharmed and the parents to recognize that the prodigy signaled the babe's future eloquence. ${ }^{15}$ When a child, Pindar fell asleep on Mt. Helicon, the very place where the Muses had inspired the poet Hesiod. He awoke to find that bees had built a honeycomb in his mouth. ${ }^{16}$ Sophocles' biographer reports that the poet's mouth was smeared with honey and that he was called the "bee" because of his poetic gifts. ${ }^{17}$ For all of the rich associations between bees, literary eloquence and poetic and prophetic inspiration, their mundane matter of living never ceased to be the most powerful sign of god's benevolent presence in the world.

\section{Classical Bees and the Ideal Society}

From the earliest times Greeks and Romans kept bees. Honey was a precious commodity. A sweetener, preservative (Col. 12.10.5) and medicinal elixir, ${ }^{18}$ honey more than justified the considerable labor a hive requires. Beeswax for candles, writing tablets and medicine made beekeeping all the more useful. ${ }^{19}$ The agriculturalist, Varro, reports that two Spaniards cleared over 10,000 sesterces a year just keeping bees (R.R. 3.16.10-11).

It is therefore not surprising that ancient zoological and agricultural handbooks devoted considerable attention to bees. ${ }^{20}$ Aristotle offers twice describes bees' life cycle, organization and behaviors in his History of Animals (Arist. HA 5.18-19; 9.27). According to Aristotle bees are among the most "political" animals even though they lack logos or reason." Bees display a social organization characterized by a political hierarchy (i.e. a king and his subjects) and division of labor that is perfectly integrated to pursue and attain a 
koivov ह้pyov, the "common labor" that characterizes all social animals (Arist. HA 1.11).22

Roman agriculturalists were captivated by the bees and their society. Varro in particular sees a microcosm of human society in the beehive. Bees teach humans to "work, build and store food" (R.R. 3.16.4).23 Just like humans, bees possess "a king, country, and society" (R.R. 3.16.6). Each member of the community is obedient, loyal and industrious. "They follow their king wherever he goes" (R.R. 3.16.8). Should he grow weary, bees will carry him on their shoulders because "they want to save him" (R.R. 3.16.8). They drive the drones who do not produce but only consume honey from the hive since they "hate idlers" (R.R. 3.16.8). In sum, whatever must be done to ensure that the hive flourishes, is-with an admirable energy, efficiency and devotion. ${ }^{24}$

For many thinkers and writers, bees did not merely display an ethos and organization worthy of admiration. Bees and their community were a divine sign. Their perfect society created by their natural habits exhibited how god's rational design pervaded the cosmos. Nowhere are these attitudes more beautifully expressed than in Vergil's widely influential Georgics. ${ }^{25}$

Vergil reiterates many of the admirable characteristics enumerated by Varro. Vergil's bees also build a monarchic state characterized by selfless devotion to the labor necessary to ensure the perpetual persistence of the hive (G. 4.149227). The traits that motivate these actions are a gift from god himself: naturas apibus quas luppiter ipse addidit... "the nature which Jupiter himself gave to bees" (G. 4.149-50). ${ }^{26}$

This poetic myth gives way to philosophic reflection as Vergil closes his account of the wondrous nature of bees with a theosophical vision of their divinity:

His quidam signis atque haec exempla secuti esse apibus partem divinae mentis et haustus aetherios dixere;

From these signs and following these examples some have said that there is to bees a share of the divine mind and a breath of fiery aether. (Verg. $G$. 4.219-21)

The later Stoic advisor to the emperor Nero, Seneca, echoes the belief that this particular insect is a potent sign of God's design in nature. Seneca enlists the bee as an example that Nature insists that a ruler possess tolerance and forgiveness, that is, clementia. The king (i.e. queen) bee is endowed with a superior body and capacity to rule, but not with a sting. Nature did not wish him so superior that he could indiscriminately take vengeance upon his inferiors (Sen. $\mathrm{Cl}, 1.19 .2-3)$. This leads Seneca to a more general observation of the bee as a particularly illuminating sign of Nature's good order: The bee is readily converted from the pagan's natural sign into an indication of the Christian God's providence. 


\section{The Christian Bee as Divine Sign}

The bee figures little in the Hebrew Bible; ${ }^{27}$ not at all in the New Testament. ${ }^{28}$ Nevertheless, the fathers of the Church readily employed the bee as a multifaceted sign. For Origen, the bee was an obvious indication of God's orderly creation. In his Contra Celsum, Origen emphatically asserts that humans are uniquely endowed with reason (Orig. Cels. 4.74). Yet, even Origen concedes to his pagan interlocutor, Celsus, that of all the irrational animals the bee's disposition suggests a peculiar intimacy with God. The bee behaves in a coherent manner that indicates most clearly God's provident design in Nature. The hive can be held up as an example for the rulers of men to follow (Orig. Cels. 4.8182). Elsewhere, Origen offers the beehive and honey as allegorical symbols of the teachings of its prophets and apostles. ${ }^{29}$ Bee society is a paradigm for the ideal community of believers with Christ as its king bee (Orig. Hom. in Is. 2.2).

Ambrose of Milan, the patron saint of bees, offers an extended description of the wonders of bee society and the features that are most worthy of Christian admiration and emulation in his Hexameron. Bees share everything in common: labor, food, even their offspring (Hexam. 5.67). They elect a king based upon merit and once they have loyally support and serve him (Hexam. 5.68)-perhaps as a Christian community should its bishop. The perfect hexagonal form of the honeycomb, specialization of labor and willingness to die fighting to preserve the hive (Hexam. 5.69) are all qualities held up for admiration just as his pagan antecedents whom Ambrose echoes in several places. ${ }^{30}$ In short, a Christian would do well to follow the injunction of Prov $6: 8 \mathrm{a}-\mathrm{b}::^{31}$

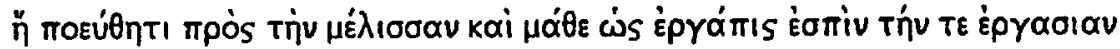

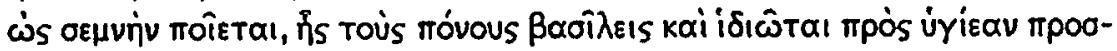

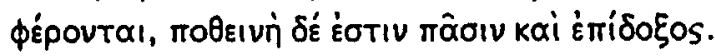

Look to the bee, what a worker she is and how serious her labor; whose toils kings and commoners harvest for their own health; labor that is desired by all and renowned to all.

Ambrose's exhortation could easily be multiplied as any number of Church fathers pointed to the bee as a symbol of and paradigm for an ideal Christian and Christian community. ${ }^{32}$

The pagan bee was also malleable enough for Christians to transform from a source of divine inspiration into a conduit for divine revelation. As noted earlier, later biographers often attributed the poetic eloquence of literary masters to divine inspiration. That inspiration was expressed in a prodigious visitation of bees. Paulinus of Milan appropriates this very anecdote in his "Life of Saint Ambrose:" 
And so when his father Ambrose was administering the prefecture of the Gauls, Ambrose was born. The infant was placed in a cradle in the courtyard of the praetorium. All at once, as he slept with his mouth open, a swarm of bees came and covered his face and mouth in such a way that they would go in and out [of his mouth]... Even then, in his infancy, the Lord was at work in his servant, so that what he said might be fulfilled: 'Good words are a honeycomb' (Prov. 16:24). For that swarm of bees produced for us the honeycombs of his writings, which would tell of heavenly gifts (coelestia dona) and raise the minds of human beings from earthly things to heaven. (Paulinus Life of St. Ambrose 3) (33 $^{33}$

Here Ambrose's innate euglottian does not attract bees to the infant; this swarm of bees is heaven-sent to fill young Ambrose with the "honeycomb" that he will bring forth in his adult writings. Rather than an indication of prodigious eloquence, the bees are guarantors of the orthodoxy of Ambrose's teachings. Bees have become instruments by which the one true God reveals exclusive truths to his devotees.

Paulinus calls those truths "coelestia dona." This is precisely the phrase that Vergil uses to describe honey at the outset of the 4th Georgic: "aerii mellis caelestia dona" (Verg. G. 4.1). ${ }^{34}$ Borrowing Vergil's turn of phrase to convert the heavenly dew that bees were thought to collect into the words of God illustrates how the Christians turned honey from a pagan's divine sign into a Christian revelation.

It was widely believed in Antiquity that bees did not produce honey but simply collected it in the form of dew that fell from the sky. ${ }^{35}$ They carried it back to the hive and regurgitated it. ${ }^{36}$ By this simple natural act a bee selflessly produced a great good thing for its own community as well as humankind. Vergil's poetic expression of this widespread "scientific" belief clearly presages the poet's subsequent description of the bee's divinity. Such a wondrous result from a simple act of a tiny insect is surely a powerful sign of its peculiar divinity and of Nature's good order. Paulinus remakes the image in the form of Christian revelation. "Caelestia dona" is no longer a physical substance (dew) and a natural behavior (bee's cosseting it away to their hive) that is a sign from nature. His "coelestia dona" is akin to manna from heaven. ${ }^{37}$ This is not just a random swarm that unwittingly foretells an infant's adult eloquence. This heavenly host of bees is divinely directed to engender the words of God into the mouth of his chosen instrument. Honey is God's Truth, not Nature's Beauty. ${ }^{38}$

Despite the translation of the Classical bee into the idiom of a sectarian discourse, the insect throughout Classical and Christian antiquity persistently encapsulated a stable set of general cultural ideals. The society bees built by nature was an ideal to admire and emulate; the individual bee possessed an enviable disposition characterized by self-sacrifice, loyalty, thrift and industry. 
Would that humans imitate its example. Their purity and honey imbued them with an intimate association with the divine. They inspire eloquence; they disclose divine wisdom. Whether by virtue of the very life they led or as a privileged herald of God's message, bees throughout Classical and Christian Antiquity were numinous creatures-sacred of god and teachers of men. ${ }^{39}$

The bee's numinous nature persists within the quranic context, but with notable differences. The portrayal of the bee as a noble recipient of the Lord's revelation [wa awha rabbuka ila 'l-nahli] stands on the fringes of the Quran's usual treatment of the transmission of God's word, which is passed through angels, prophets and other righteous human beings. ${ }^{40}$ That an insect would receive a revelation makes sense only when viewed in light of Classical and non-biblical Christian antecedents, where bees commonly and frequently serve as transmitors of divine signs or revelations, and honey becomes inextricably entwined with divine knowledge or wisdom.

However, as the quranic bee is absorbed into the Islamic exegetical traditions, its ancillary symbolism clearly derived from Classical and Christian sources falls away. The bee becomes a rhetorical trope of a very different stripe. In general, the Quran embraces the bee and the divine, revelatory wisdom it produces, though mutes it to conform more closely to the broader themes it reinforces. Traditional commentators, physicians and other Muslim literati further displace the bee from its Classical and Christian locus by depicting it in completely mundane, concrete terms that subjugate the bee to the same natural and divine laws that govern all of God's creations. Only in Sufi and Shi'ite works, which play off the fragility of the line between human and divine, does the bee continue to assert its revelatory significance. However, even in these contexts, the bee makes a rare and infrequent appearance as these gnostics look to other symbols to embody their divine truths.

\section{The Quranic Bee}

The Quran's sole reference to the bee appears in the Sura with the same title, "Surat al-nahl."

And you have in cattle a lesson:

We give you to drink from what is in their bellies [butunihi],

from between the feces and the blood, pure milk,

palatable to those who drink;

And from the fruits [thamarat] of the date-palm [al-nakhil] and the grapes,

From which you take an intoxicant [sakar] and good food.

In that [saying] is a sign for a people who have intelligence.

Your Lord revealed ['awha rabbuka] to the bee [al-nahl], "Take your houses 
From the mountains, from the trees, and from the trellises they [humans] erect,

Then eat from all fruits [thamarat] and follow the ways of your Lord [rabbiki], made smooth."

From their bellies [butuniha] a drink of various colors [sharabun mukhtalifun] comes forth,

In it, a healing for men [fihi shifa'un lill-nasi].

In that [drink] is a sign for people who give thought. ${ }^{41}$

The Quran bundles all three of these drinks, milk, the intoxicant and honey, together into a single, literary trope through metonymy and metaphor. The metonymic framework is pieced together through the repetition of vocabulary and key phrases: cattle consume food that undergoes some sort of change between their feces and their blood, the drink produced from such a change then shifts to the beverage that is miraculously produced from the fruits of the date palm and grape. The fruits [thamarat] are again repeated in the section on the bee; the fruits [thamarat] that go into belly of the bee are divinely transformed into the "drink of various colors" that comes out. Bellies [butun] link the cow and the bee together. The repetition of the sign phrase connects the intoxicant section with the bee section, in addition to the similarity of the words "nakhil" and "nahl."

The metonymical association between the cattle and the bee becomes even more significant in light of Classical antecedents. Pliny, Ovid and Vergil all declare bees are spontaneously generated from the carcuses of cows. ${ }^{42}$ The bee itself, therefore, stands as a symbol of incarnation, of renewed life from death, the theme expressed verbatim just prior to this section, in v. 65, which states "God brings down water from the sky so as to enliven the earth after its death. In that is a sign for a people who hear [wa Allahu 'anzala mina al-sama'i ma'an fa'ahya bihi al-'arda ba'da mawtiha 'inna fi dhalika la'ayatan liqawmin yasma'una]." The three drinks, then, when clustered together into a single rhetorical trope, demonstrate God's supreme ability to transform one substance into another, and perhaps more importantly, his ability to generate something useful and good from what is fleshly, putrid and rotten. Similar to the views of Paulinus, the quranic passages glorify these drinks as signs of God's ability to transform substances into forms that are beneficial to humans because he does so in ways totally unbeknownst to humans. It is not that God is able to generate such wonders because he is some sort of ideal farmer; rather, he alone fashioned the cow, the bee, the grape and the date to produce these natural goods for human consumption. Only the true believer will recognize how these agricultural gifts serve as signs to ignite deeper understandings of God's greatness.

Classical antecedents highlight further some of the textual peculiarities of the bee, namely, that the bee is a non-human recipient of the Lord's revelation, an instance occurring only one other time in the Quran. The only other mention of 
a non-human recipient of God's revelation takes place in Surat al-zalzala, when, on Judgment Day, the earth will tell all of her news, as her lord revealed to her [bi'anna rabbaka 'awha laha] (Sura 99:5). That an insect could receive what is ordinarily reserved for prophets and angels makes sense only when viewed in light of Classical and Christian antecedents, where bees commonly serve as transmitors of divine communication. In the Life of Plato and the Life of Ambrose, as noted above, bees landing of the lips of a man give him the authority to prophesy; in Pindar, the Delphic Bee sends a swarm to conduct men to the oracle.

Notable also is the quranic depiction of the drink that comes forth from the bee's belly, which contains a healing [shifa] for humans. The almost gnostic view of a drink of various colors containing a healing for humans here has little to do with honey's medicinal properties well-documented in other Islamic sources. In these ayat, what comes from the abdomen of the bee is equated with the curative power [shifa'] of the divine word itself, since the "it" could refer to the "drink," to the saying itself, or even to the Quran as a whole.

Despite the fact that a number of commentators assert the healing in this particular verse is contained in the drink and not in the word, the concept of a "healing word" was, in fact, embraced by a number of scholars. ${ }^{43}$ According to Ibn Majah, for example, the two sources of human healing are honey and the Quran. ${ }^{4}$ In an account recorded by Abu Dawud, a man came to Muhammad and told him about a dream in which he saw ghee and honey dripping from a piece of cloud. In his dream, the people were spreading their hands out to catch what the cloud expelled. Some took much; others took little. Abu Bakr interprets the dream, saying:

the piece of cloud is the cloud of Islam; the ghee and honey... are the Qur'an; which contains softness and sweetness. Those who receive much or little of it are those who learn much or little of the Qur'an.45

Here, the honey that falls from the sky (like manna from heaven) is really the Quran; both honey and the Quran function in a șimilar way to the "honeycombs" of Ambrose's divinely inspired words. The metaphorical link between honey and divine word, or nectar and divine mercy, has obvious Christian antecedents, which may inform these images.

As the Quran draws upon these Classical and Christian antecedents to elevate the bee as a bearer of God's revelation, it simultaneously mutes the magnitude of the bee's role by relegating this insect and the honey God produces through it as yet another sign of God's greatness. In this way, the quranic bee, as recipient of a revelation, deviates from its Classical and Christian past to create a new identity separate from other late antique bearers of God's word. The Quran uses these Classical and Christian images of the bee's vital and unique role in the dissemination and proof of the divine word, 
but distances itself from the forms of religiosity such a role implies, that is, multiple sources for revelation, the presence of elite interpreters of that revelation, ecstatic experience and gnosis. The end result subjects these privileged expressions of religiosity, along with those individuals who embrace them, to the supreme will of God.

Surat al-nahl subdues such privileged forms of religiosity implied by the prophetic role of the bee by lacquering Q 16:66-69 with layers of examples that echo the theme that only God can serve as the sole source of all natural, social and sacred phenomena. For example, God gives humans domesticated animals, such as horses, mules and donkeys, which they may ride or show (Sura $16: 8$ ), the animal skins people shape into tents for cover (Sura 16:80), and the coats of armor soldiers wear to protect themselves in battle (Sura 16:81). He also bestows upon men the women through whom sons and grandsons come forth (Sura 16:72). On a few occasions, the Sura depicts God as the engineer who constructs the ships that plough through the ocean (Sura 16:14), or the roads that take his followers from one place to another (Sura 16:15).

These examples do little to distinguish between what is physically beneficial and what is socially and sacredly "good." What God ultimately reveals to the bee is not a word only a few can profess, interpret or discern; rather, it is a generic blueprint for how to construct her home in ways not replicated by humans, and a recipe for how to make honey in ways mysterious to humans. It is through the divinely directed natural processes taking place within the bee that allow her to accomplish both of these feats in ways mysterious to humans. The bee, however, is not alone in her ability to produce such wonders; these same processes are at work within the domestication of the donkey and the cow and the fashioning of animal skins to shade people from the sun and the construction of the road. As a result, the bee not only stands as a unique, divinely inspired bearer of God's word, in the Classical and Christian sense, but also as a mere receptacle for one of the many physical, natural and social signs of God's greatness evident to anyone who believes. It is the latter view, which downplays the bee's uniquely prophetic role; that Muslim scholars seek to cultivate.

\section{Sunni Exegesis}

To varying degrees and in different ways, Sunni exegetical texts sever the bee from its Classical and Christian loci by depicting it in completely mundane, concrete terms. Sunni exegetes describe the bee as an animal that produces a sweet concoction that is either consumed or regulated like any other substance; it is not a hierophant endowed with a privileged status. The exegetes, in their commentaries, alienate the bee from its intimacy with God by interpreting the verb "to reveal" in ways that dilute the potency of what the bee directly 
receives. For example, Ibn Kathir notes the intended meaning of the "revelation" [wahy] is actually the divine inspiration [ilham], guidance [hidaya] and instruction [irshad] God gave the bee to take from the mountains houses and to seek shelter therein, and to construct their masterful, hexagonal structures. ${ }^{46}$ Zamakhshari suggests that God first granted the bee its inspiration [ilham], and then entrusted it with its knowledge and cleverness to construct its houses. ${ }^{47}$ Tabari also suggests that the Lord first "inspired" the bee, and then "revealed" to it to take from the mountains her houses. ${ }^{48}$ By suggesting that what the bee received was really guidance, instruction and inspiration to build her magnificent homes, the exegetes successfully distance the quranic bee from the Christian bee, who serves as a privileged instrument through which the one true God reveals exclusive truths to his devotees.

Like Ambrose, Sunni Muslim exegetes also consider how the bee serves as a model for human society to emulate. Here, however, it is not the hierarchical structure of the hive, or the work ethic of the drones, that is lauded, but rather the bee's complete subservience to the will of God. As Abu 'Uthman 'Amr b. Bahr b. Mahbub al-Jahiz observes:

Consider how bees congregate to make honey and prepare hexagonal cells adapted to their needs. If you observe their work you will find it amazingly skill ful. If you evaluate the product you will find it full of noble significance for mankind. If you look at the workers they are stupid and ignorant, unaware of themselves, let alone of others. Here is the clearest evidence that the perfect adaptation of the work of bees to its purpose comes not from the bees themselves, but from Him who created them in this way, and subjected them to human beings in their labor, to humanity's gréat advantage. ${ }^{49}$

This description of the bee and its hive strongly parallels that of Vergil; however, Vergil in no way would depict bees as "ignorant" or "unaware of themselves, let alone of others." The Islamic bee, in contrast to the Roman bee, is not to be emulated, for true emulation would be impossible, since God alone determines the habits of the bee. The bee is not a noble, social creature, but a vessel through which God's signs and gifts to humanity are revealed. ${ }^{30}$

\section{Honey in the Tibb al-Nabawi}

The Islamic medical literature strongly emphasizes the link between honey and the Quran. The medical literature states emphatically that any healing substance in and of itself will have scarce benefit without the necessary ingredient of faith. For example, if a patient suffers from a stomach ailment, she might ingest honey, but it would only be effective if accompanied by a strong desire to seek God's blessing through it." According to Zamakhshari,

a man came to the prophet and said, "My brother is complaining about his bowels. So he said, "Go and [tell him to] drink honey." So he went out, and 
then returned. He said, "I made him drink [it] but it was of no benefit." So [the Prophet] said, "Go and make him drink honey. God holds true, and the belly of your brother lies." So he made him drink [honey], and God healed him. ${ }^{52}$

Clearly the lesson to be learned is honey heals not because of its own inherent, natural properties, but because God wills it to be. One physician even suggests that hypocrites can in no way benefit from the medicinal properties of honey. This failure is not due to any defect in the medicine, but rather "their evil nature, distorted physique and ultimately their reluctance to accept such healing."

With God's role as the source of all healing secured, the physicians are free to explore in great detail honey's exceptional therapeutic properties. In general, honey is particularly suited for, but not limited to, those illnesses that disrupt human waste production. In general, the Prophet states the application of honey is one of the three most effective remedies one can practice, along with cupping [hijama] and cautery [kayy]. ${ }^{54}$ Following the Greek theory of humors, physicians assert honey is hot and dry. ${ }^{55}$ As such, it provides relief from diarrhea ${ }^{56}$ and gas, $^{57}$ excess phlegm ${ }^{58}$ and diseases of the liver, spleen, kidneys and bladder. ${ }^{99}$ In addition to its benefits to the human gastrointestinal system, lupins with honey kill worms. ${ }^{60}$ Honey blended with pomegranate seeds clears the eye of disease. ${ }^{61}$ When rancid butter made from cow's milk is mixed with honey, it serves as an antidote to poisons. ${ }^{62}$ Honey is also good for the memory. ${ }^{63}$ According to 'Arib b. Sa'd, honey mixed with milk and consumed immediately before the sexual act excelerates the passions. ${ }^{64}$ As discussed in Greek and Roman medical lore, honey was also used as a powerful preservative for meats, vegetables and even dead bodies, in the Islamic context. ${ }^{65}$ The potency of honey for living an optimal life and its role as a preservative is not surprising, given how streams of honey that remain "forever cloudless" [musaffan] permeate the eternal, static Garden of Repose (Sura 47:15).

The extraordinarily curative benefits of honey, however, are countered and tempered by its status as a beverage that has the potential to ferment [al-bit ${ }^{\prime}$. In order to create al-bit', humans must consciously act to induce fermentation by infusing honey with water. Because of its potential to transform into an intoxicant in the hands of a human agent, honey requires social and legal constraints. For this reason, perhaps, the Prophet rejects honey in addition to wine on his mi'raj:

Abu 'Asim: al-Awza'i: Ibn Shihab: 'Ubaydallah: Ibn 'Abbas: The messenger of God drank milk then rinsed his mouth and said, "It contains fat." (Ibrahim b. Tahman: Shu'ba: Qatada: Anas b. Malik) He added, "I was raised to the Lote Tree and saw four rivers, two of which were coming out and two going in. Those that were coming out were the Nile and Euphrates, and those that were going in were two rivers in Paradise. Then I was given three bowls, one containing milk, another honey, and a third wine [khamr]. 
I took the bowl containing milk and drank it. It was said to me, "You and your followers will be on the right path." 66

Honey is listed as one of the substances from which wine [khamr] can be made. ${ }^{67}$ Because khamr disturbs [khamara] the mind, any substance with that potential is condemned in the legal tradition. The suspicion that honey may corrupt the mind stands in direct contrast with honey's medicinal qualities, which, when mixed with faith, have the potential to cure body and mind. ${ }^{68}$ Here, the desire to exert control over honey's ambiguous status mirrors the exegetical impulse to temper the Christian vision of honey as God's truth.

Given the bee's strong associations with prophecy and divine word in the Quran, one might expect honey to be deeply embedded in the life of the Prophet. Certainly, the sources portray the Prophet as a lover of honey and sweets. ${ }^{69}$ In the Christian context, honey on a prophet's lips is hardly unusual. However, rather than leading him to divine speech, in the Islamic context this desire for honey only gets Muhammad into trouble with his wives. According to a number of Sunni hadith, the Prophet used to spend extra time with Zaynab $^{70}$ because she offered him honey at her house. Being jealous of the extra time spent with Zaynab, drinking her "honey," Aisha told the wives that whomever the Prophet visits after he leaves Zaynab should tell him how bad his breath smelled from the honey he consumed. Aisha states, "Say to him, "Its bees must have sucked from the'urfut flower." "71 Here, the Prophet is forced by his other wives to "cut his time short with Zaynab, for her "honey" was putrid." Quite poignantly, honey is no longer the source of divine wisdom uttered from the mouth of the Prophet, but a bad smell emanating from his breath. Clearly this episode depicts honey's fall from divine word, or even divine cure, to bilious gas rising from the bowels of men up onto their lips. ${ }^{73}$

\section{The Bee in Shi'ite and Sufi Literature}

Strangely, while the Christian view of the bee as the bearer of God's revelation echoes in both Suf and Shi'ite writings, most sources do not enlist the revelatory bee to put an authoritative stamp on their somewhat idiosyncratic tradition. Ibn 'Arabi, for example, in his tafsir, is completely silent on what God revealed to the bee in 16:67. ${ }^{74}$ The one exception can be found in Shi'ite exegesis. The Shi'ites reject Classical and Christian notions of the bee's explicit divinity, but still retain the strong associations between bees and prophethood, and honey and divine word. Al-Qummi, for example, finds no reason to mute God's revelation to the bee with inspiration, guidance or knowledge; rather, God reveals his message directly to the bee:

[y]our Lord revealed to the bee [wa awha rabbuka ila 'l-nahli]. He said, "We are the Bee to whom God revealed (who take houses from the mountains). He commanded us to take from the Arabs a Shi'a. (And from the 
trees), He said from the Barbarians. And from the trellises they erect, $\mathrm{He}$ said from the clients [mawali]. And (from their bellies a drink of various colors come forth) the knowledge ['ilm] that comes forth from us to you."

The Imam, too, serves as the direct recipient of revelatory inspiration.

In Sufi literature, the bee's status as the recipient of a direct "word" from God also persists. For example, according to Ahmad b. Idris,

The novice, in his food, avoids land and sea animals and anything that comes from them, such as milk and fat, for these foods induce the carnal lusts-except honey, as honey induces gnosis because there are traces of revelation in it: "Your Lord gave revelation to the bees" (16/68). Indeed, the sweetness of the divine address became infiltrated into bees and has remained in their progeny who inherit it from generation to generation. They eat bitter things which become sweet in their stomach, as one observes. Moreover, God has said, "Therein is a remedy for men" (16/69), i.e. both physically and spiritually because its fundament is the divine address which. is the Qur'an, the word of God. And the Qur'an is a remedy for what is in man's breast, and the right guidance and mercy for the believers. ${ }^{76}$

The Sufi portrayal of the bee also emphasizes honey as a form of gnosis passed down from one privileged generation to the next. Still, none of the sources trace a literary genealogy from themselves back to the bee. There is no honey on the lips nor "honeycomb" of writing that embellishes and enriches God's original revelation to the bee. It remains a surface-level association rather than an alternative avenue to divine wisdom. Ultimately, there is still only one true prophet, and one true word of the one true God.

\section{The Classical and Christian Echoes}

As the bee becomes absorbed into the Islamic exegetical tradition, its ancillary symbolism clearly deriyed from Classical and Christian sources falls away. The lack of interest in developing an elaborate metonymical or metaphorical palate for the bee and its honey may be due in part to the fact that in Classical and Christian contexts, bees occupy pastoral — not urban or nomadic-landscapes. In the Islamic literary tradition, the bee finds a rare home in a Sura unique in its embellishment of agricultural imagery, which includes elaborate descriptions of crop production, sheep herding, animal husbandry, the raising of cattle for milk and meat and the fluctuating cycles of nature and seasons. Outside the literary boundaries of this particular Sura we see little interest in the further development of Classical and Christian pastoral or agricultural tropes. Although the Quran was revealed in a non-agricultural environment, the Islamic tradition still admired the bee's intricate, hexagonal structures and its mysterious production of honey; however, the focus shifted necessarily from the perfected nature of the bee to the divine word carried by the bee to the divine creator who 
fashioned the bee to construct geometric wonders, and to produce an ideal medicine for human diseases (provided those in dire straits had faith). While the bee still possesses an intimacy with God few other creatures share, ${ }^{\text {" Mus- }}$ lim scholars and exegetes hold that what God instructs the bee to do is not unique but is only one of many signs and gifts for humans to behold.

\section{Notes}

* Abbreviations of authors, works and academic journals follow the editorial guidelines of the American Journal of Archaeology. Abbreviations of the biblical materials follow those prescribed by New Testament Studies. All translations of Greek, Latin and Arabic are our own unless otherwise indicated.

1. Throughout the Quran, the verb awha is solely used with prophets or other individuals who are the direct and privileged recipients of God's message. For example, Noah, Abraham, Ishmael, Isaac and Jacob were the recipients of a revelation in Sura 4:163; Moses in 26:63.

2. Cass. Dio 41.61.2, 42.26.1, 47.2.3, 47.40.7, 56.24.4, 74.6.3, 78.25.1; cf. also Cic. Har. 25; Livy 24.10.1 1,27.23.3; Lucan 7.161; Pliny Nat. 11.55; Tac. Ann. 12.64; Sil. It. 8.635; Amm. Marc. 18.3.1; Plutarch, Dion 24; Brutus, 39, 48. For bee swarms as portending good: Cic. Div. 1.73, Pliny Nat. 8.158 (both sources recount how Dionysius's horse was attacked by a bee swarm on the day he assumed control of Syracuse). Cf. RE "Biene," col. 448; W. H. Robert-Tornow, De Apium Mellisque Apud Veteres Significatione Et Symbolica Et Mythologica (Berlin: Weidmann, 1893), 43-57. Cf. Pliny Nat. 11.18.55 where he records bee swarms portending good in contrast to their generally dire forecasts.

3. But not always; see Plut. Dion 24.

4. Cf. Philostr. Im. 2.85 where the Muses in the form of bees lead the Athenians to Ionia.

5. For the complete story, consult Paus. 9.37.5-8.

6. For bees as prophetic in general, see H. M. Ransome, The Sacred Bee in Ancient Times and Folklore (London: George Allen \& Unwin, 1937), 96-99, 108-11; A. B. Cook, "The Bee in Greek Mythology," JHS 15 (1895): 7; Robert-Tornow, De Apium Mellisque Apud Veteres Significatione Et Symbolica Et Mythologica, 3539; H. Usener, "Milch und Hönig," in Kleine Schriften, vol. 4, ed. L. Radermacher (Leipzig: B.G. Teubner, 1912), 400 and S. Scheinberg, "The Bee Maidens of the Homeric Hymn to Hermes," HSCP 83 (1979): 1-28.

7. Concerning the myths of the temples at Delphi generally, see C. SourvinouInwood, "The Myth of the First Temples of Delphi," CQ 29, no. 2 (1979): 23151.

8. P. Murray, Plato on Poetry: Ion; Republic 376e-398b9; Republic 595-608b10 (Cambridge: Cambridge University Press, 1996), 117-18. Cf. N. K. Chadwick, Poetry \& Prophecy (Cambridge: Cambridge University Press, 1952); J. L. Kugel, Poetry and Prophecy: The Beginnings of a Literary Tradition (Ithaca: Cornell University Press, 1990).

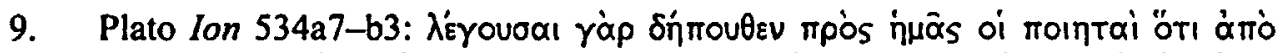

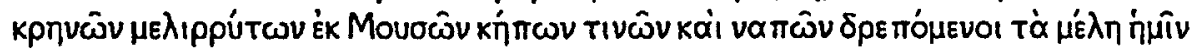




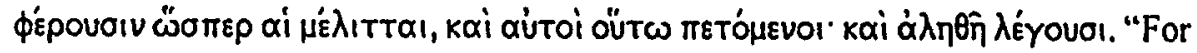
the poets say (as l am sure you know) that they bring their songs to us, flying about just as bees culling sweet-flowing nectar from certain founts and gardens of the Muses. And they are telling the truth."

10. See for instance, Eur. Hipp. II. 73-81 with Barrett's comments (W. S. Barrett, Euripides Hippolytos [Oxford: Clarendon Press, 1992], 170-75). Ancients persisted in the mistaken belief that bees reproduced asexually. (They also mistook the queen for a king). See, for example, Arist. HA 5.18.1; Verg. G. 4.197-202; Pliny, Nat. 11.16.46. For Christians, the bee thereby became emblematic of chastity. See for instance, Ambr. de Virg. 1.8.41.

11. We find this same image in the fifth-century comic poet Aristophanes' Birds

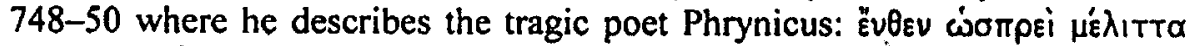

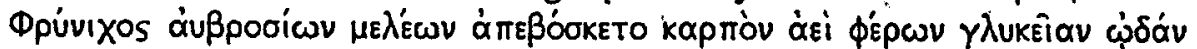
("like a bee he sucked the fruit of melodies immortal, ever carrying away sweet song" (trans. Lefkowitz in M. R. Lefkowitz, The Lives of the Greek Poets [London: Duckworth, 1981], 80). Cf. Plut. Mor. 32e, 4le-42b, 79d, 145b, 467c, 765d. See E. K. Borthwick, "Bee Imagery in Plutarch," CQ41, no. 2(1991): 560 and $\mathrm{n} .1$.

12. Callimachus as hardly alone in this respect as poet's and poetry were often compared to bees and honey. See J. H. Waszink, Biene und Hönig als Symbol des Dichters und der Dichtung in der griechisch-römischen Antike (Opladen: Westdeutscher Verlag, 1974) and Scheinberg, "The Bee Maidens of the Homeric Hymn to Hermes."

13. Varro, R.R. 3.16.7: "cum Musarum esse dicantur volucres."

14. See for example: Homer II. 1.247-49, Od. 8.170-73; Hes. Th. 39-40, 83-84; Lucr. 4.22; Hor. Ep. 1.19.44.

15. This anecdote is told of Plato by several, most fully by Claudius Aelianus (Var. Hist. 10.21). Cf. Cic. Div. 1.78, 2.66; V. Max. 1.6 extr. 4; Pliny, Nat. 11.18.55.

16. Vira Pindari Ambrosiana 1.6-11 and Lefkowitz, The Lives of the Greek Poets, $59,155-56$.

17. Vita Sophoclis, 11. 87-89, 93-94 and Lefkowitz, The Lives of the Greek Poets, 163.

18. See, for example, Pliny Nat. 22.50.107-9 and Dsc. de Materia Medica 2.82.

19. Note at the close of his de Re Rustica (9.16.1), Columella explicitly notes that wax is not particularly profitable but extremely useful. For its medicinal properties, see Pliny Nat. 22.52.112. Cf. Varro's report that "erithace" or "bee-bread" was used by physicians to make casts. It was more expensive than honey $(R . R$. 3.16.23).

20. Ancients remained curiously ignorant of several facets of bee behavior. See supra n. 10.

21. Arist. Pol. 1253a7-8. In Aristotle's parlance, to be "political" is to live in a polis, that is a coherent integrated society with laws, customs, and government institutions. Though Aristotle in general tends not to anthropomorphize bees, his description does presume a semi-rational social and political organization. Cf. Xen. Oec. 7.32-34 where bees are held up as a social ideal. 
22. Other social animals include (but is not limited to), humans, bees, wasps, ants and storks (Arist. $H A$ 1.11).

23. (In contrast to jackdaws) bees have "...ratio atque ars, ab his opus facere discunt, ab his aedificare, ab his cibaria condere" ("...reason and also established methods; from these they learn to work, build and store provisions [R.R. 3.16.4]).

24. Varro is hardly unique in his enthusiasm for bees. Pliny the Elder in his account of bees declares "bees have mores that outstrip all other animals" ("mores habent praeter cetera" [Pliny Nat. 11.4.12]). Cf. Cic. Off. 1.157.

25. There is a wide variance in the degree of optimism or pessimism critics detect in Vergil's works in general and the Georgics in particular. Are bees an unqualified paradigm model for human society or is the overt idealism tempered by a darkly ironic undertone? Dahlmann's ideal Bienenstaat (J. H. Dahlmann, Der Bienenstaat in Vergils Georgica [Mainz: Akademie der Wissenschaften und der Literatur, 1955]) is answered by Putnam's general pessimism (M. C. J. Putnam, Virgil's Poem of the Earth: Studies in the Georgics [Princeton: Princeton University Press, 1979]) and Parry's specific circumspection (A Parry, "The Idea of Art in Vergil's Georgics," Arethusa S [1972]: 35-52). J. Griffith, "The Fourth 'Georgic', Virgil, and Rome,".Greece \& Rome 26 (1979): 61-64 well summarizes some of the ironies and ambivalence surrounding Vergil's bees. Be that as it may, there is no doubting the explicit positives of Vergil's account and that many of his ancient readers fastened upon them. An extremely positive reading of Vergil's bees is especially noticeable in Ambrose's Hexameron. In addition to Vergil's account of bees, his more general influence on later poetry and thought is impossible to summarize or overestimate. As Marrou states, "un Romain cultivé est un homme qui possède son Virgile." (H. I. Marrou, Histoire de l'education dans l'antiquité (Paris: Éditions du Seuil, 1948), 341. For a recent, detailed analysis of certain early Church Fathers' use of Vergil, see S. Freund, Vergil im friihen Christentum : Untersuchungen zu den Vergilzitaten bei Tertullian, Minucius Felix, Novatian, Cyprian Und Arnobius (Paderborn: Schöningh, 2000).

26. According to a widely circulated myth, when Jupiter/Zeus was an infant, his mother Rhea hid him in a cave in Crete. Bees fed the baby Zeus. In return for his sustenance, the king of the gods gave bees their peculiar nature. Cf. Callimachus Hymn 1.48-50.

27. Apart from the vivid image of Samson scooping honeycomb from the carcass of a slain lion swarming with bees (Judg 14:8-9) and infrequent use as a simile for martial behavior (Deut 1:44; cf. Ps 118.2; Isa 7:19; 4 Macc. 14:19), bees do not figure prominently in the Hebrew Bible. See infra $\mathrm{n}$. 31. References to honey occur much more frequently though a very large minority (twenty-seven of sixtyeight occurrences) and are found in the phrase "land of milk and..." Interestingly "honey" can serve as a negative image for seductive speech. According to Prov. 5:3-4: "For the lips of a loose woman drip honey, / and her speech smoother than oil; / but in the end she is bitter as wormwood, / sharp as a two-edged sword.

28. Bees do not appear in the New Testament, but honey does. John the Baptist is said to live on locusts and wild honey (Mark 1:6 = Matt 3:4) while John the Revelator finds the scrolls he ate taste "sweet as honey" (Rev 10:10). 
29. Orig. Hom. in Num 17.12 (on Num 33:45). Cf. Hom. in Is. 2.2. M. Misch, Apis Est Animal, Apis Est Ecclesia: Ein Beitrag zum Verhältnis von Naturkunde und Theologie in Spätantiker und Mirtelalterlicher Literatur (Bern: Peter Lang, 1974), 25-31.

30. For list of general sources for Ambrose, see Misch, Apis Est Animal, Apis Est Ecclesia, 43. For a detailed discussion of the verbal echoes of Georgic 4 in Hexam. 21.66-72, see Misch, Apis Est Animal, Apis Est Ecclesia, 45-48.

31. These verses appear only in the Septuagint text, not the Hebrew Bible. In all likelihood the excursus on the bee crept into the text from the translator's gloss since the bee is not a positive exemplar for labor in the Hebrew tradition and so is certainly unlikely to cap the ant (held up as an exemplar in the two preceding verses), who is. The bee's reputation in the Graeco-Roman world in all likelihood motivated the translator to expand the lesson on labor from one insect to two. See P. de Lagarde, Anmerkungen zur griechischen Übersetzung der Proverbien (Leipzig: F. A. Brockhaus, 1863), 22; C. H. Toy, A Critical and Exegetical Commentary on the Book of Proverbs (New York: Charles Scribner's Sons, 1899), 124; R. L. Giese Jr., "Strength Through Wisdom and the Bee in Proverbs Lxx-Prov 6,8A-C," Biblica 73 (1992): 404-5. Clement of Alexandria quotes this exact phrase with a similar enthusiasm to make a similar point with a slightly

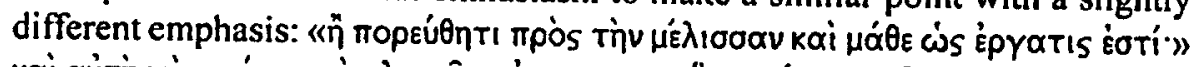

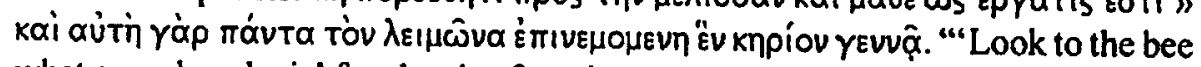
what a worker she is' for she also foraging over the entire meadow produces just one comb" (Clem. Alex. Strom. 1.6.33).

32. Other Church fathers who hold up the bee as an ethicalideal and/or symbol for a Christian community include: Orig. Hom.in Is. 2.2; Athan. in Ps. 117.2; Greg. Naz. Orat. 44.11.

33. B. Ramsey, trans., Ambrose (London: Routledge, 1997), 197. Paulinus's Latin: Igitur posito in administratione praefecturae Galliarum patre eius Ambrosio, natus est Ambrosius. Qui infans in area praetorii in cuna positus, cum dormiret aperto ore, subito examen apum adveniens, faciem eius atque ora complevit; ita ut ingrediendi in os, egrediendique vices frequentarent... Operabatur enim iam tunc Dominus in servuli sui infantia, ut impleretur quod dictum est: Favi mellis sermones boni (Prov 16:24); illud enim examen apum scriptorum ipsius nobis generabat favos, qui coelestia dona annuntiarent, et mentes hominum de terrenis ad coelum erigerent.

34. Cf. Pliny Nat. 11.12.30-31.

35. Arist. HA 5.19.4; Pliny Nat.11.12.30; Verg. G 4.1. Cf. Varro, R.R. 3.16.24-26 who rightly recognizes that bees produce honey from flowers. [Quint] Decl.13.3 conflates the two accounts.

36. Arist. HA 5.19.6; Pliny Nat. 11.12.30-31.

37. In Exod 16:31 Manna is explicitly described as tasting like honeycakes. In the pseudepigraphic romance, Joseph and Aseneth, honey becomes manna of eternal life. The Egyptian princess, Aseneth upon her conversion to Judaism partakes of a marvelous honeycomb, an angelic dainty made by the bees of paradise. Once she eats of it she will never die (Jos. Asen. 16:4-8). See C. Burchard, "Joseph and Aseneth," in The Old Testament Psetldepigrapha, vol. 2, ed. J. H. 
Charlesworth (New York: Doubleday, 1985), 228 n.f. Cf. M. Hubbard, "Honey for Aseneth: Interpreting a Religious Symbol," JSP 16 (1997): 98, 108-9 who rather tenditiously resists the identification of the honey of Aseneth with manna. Compare the vision of Pachomius in which dew descends from heaven and congeals into honey on his right hand-a symbol for the grace Pachomius receives from Christ (F. Halkin, Sancti Pachomii Vitae Graecae (Brussels: Soc. des Bollandistes, 1932], 173).

38. Cf. Ambrose's own words: Rore pascitur apis, nescit concubitus, mella componit. Ros quoque virginis est sermo divinus; quia sicut ros, Dei verba descendunt. ("the bee is fed by dew, is ignorant of intercourse and compounds honey. The virgin's dew is also divine discourse, since the words of God come down just like the dew" (Ambr. de Virg. 1.8.40).

39. This is a paraphrase of the neo-Platonist Proclus's prefatory remarks to his 13 th discourse on Plato's Republic (W. Kroll, Procli Diadochi in Platonis Rem Publicam Commentarii [Amsterdam: A. Hakkert, 1965], vol. 2:1). The full statement

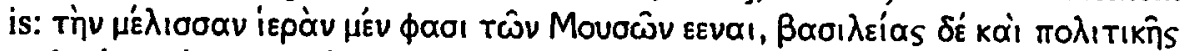

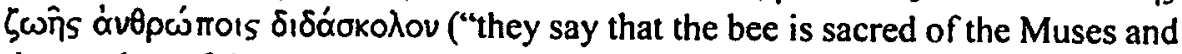
the teacher of the monarchic and political life to men").

40. See, for example, Suras 5:11 (apostles), 10:87 (Moses and his brother), 8:12 (angels).

41. Sura 16:66-69: Wa 'inna lakum $f$ 'l-an'am la'ibratan nasqikum mimma $f$ butunihi min bayni farthin wa damin labanan khalisan sa'ighan li-'sharibina. Wa min thamarati al-nakhili wa 't'a'nabi tattakhidhuna minhu sakaran wa rizqan hasanan 'inna fi dhal ika la'ayatan liqawmin ya'qiluna. Wa'awha rabbuka 'ila 'l-nahli 'ani attakhidhi mina al-jibali buyutan wa mina al-shajari wa mimma ya'rishuna. Thumma kuli min kulli al-thamarati fasluki subula fabbiki dhuluan yakhruju min butuniha sharabun mukhtalifun 'alwanthu fihi shifa'un li 'l-nasi 'inna $f$ dhalika la'ayatan ligawmin yatafakkaruna.

42. E.g., Vergil G. Bk 4. 281-314; Varro R.R. 2.5.5:3.16.4.

43. According to Ibn Qayyim Jawziya, there are two opinions regarding what actually contains the "medicine for men." Either the drink or the Quran could serve as the referent. Ibn Qayyim maintains it is the drink that contains the medicine, and not the Quran. He states the majority of the commentators hold this position (Ibn Qayyim Jawziya, Medicine of the Prophet, trans. Penelope Johnstone (Cambridge: The Islamic Texts Society, 1998), 26. Imad al-Din Abi alFida' Isma'il 'Umar b. Kathir (Tafsir al-Qur'an al-'azim [Mu'assasat Quruba: Maktabat Awald al-Shaykh li 'I-Turath, Part 8, 2000], 326-27), suggests a number of scholars, including Mujahid, support the idea that the phrase fihi shifa'un li'l-nasi refers to the Qur'an. Ibn Kathir, however, believes in this case the healing refers to the honey. Jalal al-Din 'Abd al-Rahman al-Suyuti (Medicine of the Prophet [London: Taha Publishers, 1994], 79) agrees with this assessment, along with Ibn Qayyim (Medicine of the Prophet, 26).

44. Ibn Majah, Tibb, 7, quoted in Ibn Qayyim, Medicine of the Prophet, 24.

45. Abu Dawud Sulayman b. Ash'ath al-Sijistani, "Kitab al-sunna," in Sunan Abi Dawud, ed. Muhammad Muhyi '1-Din 'Abd al-Hamid, 4 vols. (Cairo: Matba'at Mustafa Muhammad, 1935), \#4615. See also Muslim b. al-Hajjaj al-Qushayri, 
"Kitab al-ruya," in Sahih Muslim, ed. Muhammad Fu'ad 'Abd al-Baqi (Beirut: Dar al-Ihya' al-Turath, 1956-72), \#5643, \#5644.

46. Ibn Kathir, Tafsir al-Qur'an al-'azim, 324.

47. Abu al-Qasim Jar Allah Mahmoud b. 'Umar Zamakhshari, al-Kashshaf 'an haqa'ig al-tanzil wa-'uyzun al-aqawil fi wujuh al-ta'wil (Misr, al-Babi al-Halabi, 1966-68), part 2, 618.

48. Abu Jafar Muhammad b. Jarir b. Yazid b. Kathir al-Tabari, Tafsir al-Tabari min kitabihi jami' al-bayan 'an ta'wil ay al-Qur'an (Bayrut: Mu'assasat al-Risalah, 1994), 535.

49. Abu 'Uthman 'Amr b. Bahr al-Mahbub al-Jahiz, Chance or Creation? God's Design in the Universe. Attributed to al-Jahiz, trans. M. A. S. Abdel Haleem (Berkshire: Garnet Publishing, 1995), 68.

50. This view resembles that of Origen, who suggests that even though it is an irrational animal, the bee behaves in a coherent fashion, which points to the orderly nature of God's creation. Cf. Origen, Cels, supra n. 29. Likewise, hexagons are a sign to Ambrose. See supra n. 32.

51. Ibn Khaldun, Mugaddima, trans. Franz Rosenthal (New York: Pantheon Books, 1958), 412.

52. Zamakhshari, al-Kashshaf, part 2, 619. See also Muslim, "Kitab al-salam," in Sahih, \#5492; al-Suyuti, Medicine of the Prophet, 78; Abu 'Abdallah Muhammad b. Isma'il b. Ibrahim al-Bukhari, "Kitab al-talaq," in Jami" al-sahih (Cairo: Dar al-Fikr, 1981), \#588, \#615. See also Ibn Qayyim, Medicine of the Prophet, 23. According to lbn Qayyim, the reason why the man was not healed the first time had to do with the fact that his brother did not give him the correct amount (Medicine of the Prophet, 25). Thus it was not the fault of the honey to cure, but of man to administer the right dosage.

53. Ibn Qayyim, Medicine of the Prophet, 25.

54. Al-Bukhari, "Kitab al-talaq, in Sahih, \#584, \#585. Strangely, after the Prophet states healing can be found in a gulp of honey, cupping, and cauterizing, he condemns the practice of cauterizing. In \#587 and \#603, the Prophet does not condemn cauterizing, but simply states that he does not prefer to be branded with fire. Ibn Qayyim explains this contradiction by saying the Prophet recommended cautery only as a last resort, for the practice brings forth more pain than the ailment for which it is a cure (Medicine of the Prophet, 37). For the Prophet's support of only honey and cupping, see al-Suyuti, Medicine of the Prophet, 79; See also Muslim, "Kitab al-Salam," in Sahih, \#5468.

55. Al-Suyuti, Medicine of the Prophet, 80. Ibn Qayyim, Medicine of the Prophet, 72.

56. Al-Suyuti, Medicine of the Prophel, 18, 78; Ibn Qayyim, Medicine of the Prophet, 24.

57. Ibn Qayyim, Medicine of the Prophet, 208.

58. Al-Suyuti, Medicine of the Prophet, 80; Ibn Qayyim, Medicine of the Prophet, 23.

59. Al-Suyuti, Medicine of the Prophet, 80; Ibn Qayyim, Medicine of the Prophet, 165. 
60. Al-Suyuti, Medicine of the Prophet, 44.

61. Ibn Qayyim, Medicine of the Prophet, 226.

62. Al-Suyuti, Medicine of the Prophet, 69. Ibn Qayyim, Medicine of the Prophet, 232.

63. Ibn Qayyim, Medicine of the Prophet, 243.

64. 'Arib b. Sa'd al-Qurtubi, Kitab khalq al-janin wa tadbir al-habala' wa 'lmawludin (al-Jaza'ir: Maktabat Farraris, 1956), 16.

65. Al-Suyuti, Medicine of the Prophet, 80. Ibn Qayyim notes that honey not only preserves meat, squash, cucumber, gourd and aubergine, but also dead bodies (Medicine of the Prophet, 23-24).

66. AJ-Bukhari, "Kitab al-ashriba," in Sahih, \#514.

67. For hadith statements on the condemnation of honey, see 'Abdallah b. 'Abd alRahman al-Darimi, "Kitab al-ashriba," in al-Sunan, ed. Muhammad Ahmad Duhman (Cairo: Dar al-Ihya', 197-), 113; Muslim, "Kitab al-ashriba," in Sahih, \#70; Abu 'Isa Muhammad b. 'Isa al-Tirmidhi, "Abwab al-ashriba," in Sahih, ed. Ahmad Muhammad Shakir (Cairo: Al-Matba'a al-Misriya, 1931-34), 63.

68. Al-Suyuti suggests only God has the power to place both a poison and a cure (simultaneously) within the bee. This wonder is clear evidence of his tawhid (Medicine of the Prophet, 62).

69. Al-Suyuti, Medicine of the Prophet, 79; Bukhari, "Kitab al-talaq," in Sahih, \#342, \#504, \#518, \#586; Ibn Qayyim, Medicine of the Prophet, 162.

70. Zaynab or Hafsa, depending on the tradition.

71. Muslim, "Kitab al-talaq," in Sahih, \#3496, \#3497. See also al-Bukhari, "Kitab al-tafsir," Sahih, \#435. See also "Kitab al-talaq," \#192, \#193.

72. The word "honey" is often used as a euphemism for sexual intercourse. See, for example, Abu Dawud, "Kitab al-talaq," in Sunan, \#2302, which states the Prophet "was asked about a man who divorced his wife three times, and she married another who entered upon her, but divorced her before having intercourse with her, whether she was lawful to the former husband. She said: The Prophet said: She is not lawful for the first until she tastes the honey ['asal] of the other husband and he tastes her honey."

73. See Prov 5:3-4, supra n. 27.

74. See Muhyi 'I-Din b. al-'Arabi, Tafsir al-Qur'an al-karim (Beirut: Dar alThaqafah al-'Arabiyah, 1968) exegesis on al-Nahl.

75. 'Ali b. Ibrahim al-Qummi, Tafsir al-Qummi (al-Najaf: Maktabat al-Huda', 1966 or 1967), 387. See also Furat b. Ibrahim b. Furat al-Kuf, Tafsir Furat al-Kufi (Najaf: al-Matba'at al-Haydariya, 1936), 84.

76. Ahmad b. Idris, "Two Sufi Treatises of Ahmad Ibn Idris," trans. Bernd Radtke, R. Sean O'Fahey and John O'Kane, Oriens 35 (1996): 143-78 (165).

77. Bees, for example, are not to be killed. Muslim, "Kitab al-jihad," in Sahih, \#10. Abu Dawud notes that four creatures are not to be killed: ants, bees, hoopoes, and sparrow-hawks ("Kitab al-Adab," in Sunan, \#5247). 


\section{References}

Abu Dawud Sulayman b. al-Ash'ath al-Sijistani. Sunan Abi Daswud, ed. Muhammad Muhyi 'lDin 'Abd al-Hamid. 4 vols. Cairo: Matba'at Mustafa Muhammad, 1935

Barrett, W. S. 1992. Euripides Hippolyros. Oxford: Clarendon Press.

Borthwick, E. Kerr. "Bee Imagery in Plutarch." CQ 41, no. 2 (1991): 560-62.

Al-Bukhari, Abu 'Abdallah Muhammad b. Isma'il b. Ibrahim. Jami'al-sahih. 8 vols. Cairo: Dar al-Fikr, 1981.

Burchard, C. "Joseph and Aseneth." In The Old Testament Pseudepigrapha, vol. 2, ed. J. H. Charlesworth, 177-247. New York: Doubleday, 1985.

Chadwick, Nora K. Poerry \& Prophecy. Cambridge: Cambridge University Press, 1952.

Cook, A. B. "The Bee in Greek Mythology." JHS 15 (1895): 1-24.

Dahlmann, Hellfried. Der Bienenstaat in Vergils Georgica. Wiesbaden: Akademie der Wissenschaften und der Literatur, 1955.

Al-Darimi, 'Abdallah b. 'Abd al-Rahman. Al-Sunan, ed. Muhammad Ahmad Duhman. Cairo: Dar al-lhya', 197-.

Freund, Stefan. Vergil im frïhen Christentum: Untersuchungen zu den Vergilzitaten bei Terrullian, Minucius Felix, Novarian, Cyprian und Arnobius. Studien zur Geschichre und Kullur des Allertums. Paderborn: Schöningh, 2000.

Giese Jr., Ronald L. "Strength through Wisdom and the Bee in Poverbs LXX-Prov 6,8a-c. Biblica 73 (1992): 404-11.

Griffith, Jasper. "The Fourth 'Georgic', Virgil, and Rome." G\& R 26 (1979): 61-80.

Halkin, François. Sancti Pachomii vitae Graecae. Bruxelles: Soc. des Bollandistes, 1932.

Hubbard, Moyer. "Honey for Aseneth: Interpreting a Religious Symbol." JPS 16 (1997): 97110.

Ibn 'Arabi, Muhyi 'I-Din. Tafsir al-Qur'an al-karim. 2 vols. Beirut: Dar al-Thaqafah al'Arabiyah, 1968.

Ibn Idris, Ahmad. "Two Sufi Treatises of Ahınad Ibn Idris," trans. Bernd Radke, R. Sean O'Fahey and John O'Kane. Oriens 35 (1996): 143-78. doi:10.2307/1580547.

Ibn Kathir, Imad al-Din Abi al-Fida' Isma'il 'Umar. Tafsir al-Qur'an al-'azim. Part 8. Mu'assasat Quruba: Maktabat Awald al-Shaykh li 'l-Turath, 2000.

Ibn Khaldun, Abu Zayd Abdu 'l-Rahman b. Muhammad. Muqaddima, trans. Franz Rosenthal. New York: Pantheon Books, 1958.

Al-Jahiz, Abu 'Uthman 'Amr b. Bahr al-Mahbub. Chance or Creation?' God's design in the universe. Altributed to al-Jahiz, trans. M. A. S. Abdel Haleem. Berkshire: Garnet Publishing, 1995.

Jawziya, Ibn Qayyim. Medicine of the Prophet, trans. Penelope Johnstone. Cambridge: The Islamic Texts Society, 1998.

Kroll, Wilhelm. Procli Diadochi in Plaronis Rem publicam commentarii. Leipzig: B. G. Teubner, 1899.

Al-Kufi, Furat b. Ibrahim b. Furat. Tafsir Furat al-Kufi. Al-Najaf: Al-Matba'at al-Haydariya, 1936.

Kugel, James L. Poerry and Prophecy: The Beginnings of a Literary Tradition. Ithaca: Comell University Press, 1990.

Lagarde, Paul de. Anmerkungen zur griechischen Übersetzung der Proverbien. Leipzig: F. A. Brockhaus, 1863.

O Equinox Publishing Lid 2009. 
Lefkowitz, Mary R. The Lives of the Greek Poets. London: Duckworth, 1981.

Marrou, Henri Irénée. Histoire de l'education dans l'antiquilé. Paris: Éditions du Seuil, 1948.

Misch, Manfred. Apis est animal, apis est ecclesia: ein Beitrag zum Verhältnis von Naturkunde und Theologie in spätantiker und mittelalterlicher Literatur. Bem: Peter Lang, 1974.

Murray, P. Plato on Poetry. Cambridge: Cambridge University Press, 1996.

Muslim b. al-Hajjaj al-Qushayri, ed. Muhammad Fu'ad 'Abd al-Baqi. 8 vols. Beirut: Dar alIhya' al-Turath, 1956-72.

Parry, A. "The Idea of Art in Vergil's Georgics. Arethusa 5 (1972): 35-52.

Putnam, Michael C. J. Virgil's Poem of the Earth: Studies in the Georgics. Princeton: Princeton University Press, 1979.

Al-Qummi, 'Ali b. Ibrahim. Tafsir al-Qummi. 2 vols. Al-Najaf: Maktabat al-Huda', 1966 or 1967.

Al-Qurtubi, 'Arib b. Sa'd. Kirab khalq al-janin wa tadhir al-habala' wa 'l-mawludin. Al-Jaza'ir: Maktabat Farraris, 1956.

Ramsey, Boniface, trans. Ambrose. London: Routledge, 1997.

Ransome, Hilda M. The Sacred Bee in Ancient Times and Folklore. London: George Allen, 1937.

Robert-Tomow, Walter Heinrich. De apium mellisque apud vereres significatione et symbolica et mythologica. Berlin: Weidmann, 1893.

Scheinberg, Susan. "The Bee Maidens of the Homeric Hymn to Hermes." Harvard Studies in CP 83 (1979): 1-28.

Sourvinou-Inwood, Christiane. "The Myth of the First Temples of Delphi." CQ 29 (1979): $231-51$.

Al-Suyuti, Jalal al-Din 'Abd al-Rahman. Medicine of the Prophet. London: Taha Publishers, 1994.

Al-Tabari, Abu Jafar Mubammad b. Jarir Yazid b. Kathir. Tafsir al-Tabari min kiabihi Jami' al-bayan 'an ta'wil ay al-Qur'an. Bayrut: Mu'assasat al-Risalah, 1994.

Al-Tirmidhi, Abu 'Isa Muhammad b. 'Isa, ed. Ahmad Muhammad Shakir. 5 vols. Cairo: AlMatba'a al-Misriya, 1931-34.

Toy, Crawford Howell. Critical and Exegetical Commentary on the Book of Proverbs. New York: Charles Scribner's Sons, 1899.

Usener, Hermann. "Milch ưnd Hönig." In Kleine schriften, vol. 4, ed. Ludwig Radermacher, 398-417. Leipzig: B.G. Teubner, 1912.

Waszink, J. H. Biene und Honig als Symbol des Dichters und der Dichtung in der griechischrömischen Antike. Opladen: Westdeutscher Verlag, 1974.

Zamakhshari, Abu 'I-Qasim Jar Allah Mahmoud b. 'Umar. Al-Kashshaf'an haqa'iqa al-ranzil wa-'uyun al-aqawil fi wujuh al-sa'wil. 4 vols. Misr, al-Babi al-Halabi, 1966-68. 
Copyright of Comparative Islamic Studies is the property of Equinox Publishing Group and its content may not be copied or emailed to multiple sites or posted to a listserv without the copyright holder's express written permission. However, users may print, download, or email articles for individual use. 